\title{
Astrocoryne cabela, gen. nov. et sp. nov. (Hydrozoa : Sphaerocorynidae), a new sponge- associated hydrozoan
}

Davide Maggioni $^{\mathrm{A}, \mathrm{B}, \mathrm{D}}$, Paolo Galli ${ }^{\mathrm{A}, \mathrm{B}}$, Michael L. Berumen ${ }^{\mathrm{C}}$, Roberto Arrigoni ${ }^{\mathrm{C}}$, Davide Seveso $^{\mathrm{A}, \mathrm{B}}$ and Simone Montano ${ }^{\mathrm{A}, \mathrm{B}}$

${ }^{\text {A}}$ Dipartimento di Biotecnologie e Bioscienze, Università degli Studi di Milano-Bicocca, Piazza della Scienza 2, 20126, Milano, Italy.

${ }^{\mathrm{B} M a R H E}$ Center, Università degli Studi di Milano-Bicocca, Magoodhoo Island, Faafu Atoll, Republic of Maldives.

${ }^{\mathrm{C}}$ Red Sea Research Center, Division of Biological and Environmental Sciences and Engineering, King Abdullah University of Science and Technology, Thuwal 23955-6900, Saudi Arabia.

${ }^{\mathrm{D} C}$ Corresponding author: Email: davide.maggioni@unimib.it

The family Sphaerocorynidae includes two valid genera and five species, most of which have a confusing taxonomic history. Here, a new genus and species, Astrocoryne cabela, gen. et sp. nov., is described from the Maldives and the Red Sea, based on both morphological and molecular evidence. Astrocoryne cabela has an apomorphy represented by the type of tentacles, here named 'dicapitate', and consisting of capitate tentacles with a halfway capitulum-like cluster of nematocysts. Molecular analyses confirmed the monophyly of this species, as well as its belonging to the Sphaerocorynidae, together with Sphaerocoryne spp. and Heterocoryne caribbensis, for which we present molecular data for the first time. Moreover, the high divergence of A. cabela from other species of the family justifies the establishment of a new genus. Interestingly, specimens from the Maldives and the Red Sea showed marked morphological variation in the polyp stage, although only a slight genetic divergence was detected. This study highlights that a comprehensive morpho-molecular assessment of Sphaerocorynidae is strongly needed in order to clarify the taxonomic issues and the diversity of this taxon.

IS16091

D. Maggioni et al.

Astrocoryne cabela, gen. et sp. nov.

TOC Summary

Additional keywords: Capitata, new genus, new species, Maldives, Red Sea.

\section{Introduction}

Hydrozoan polyps are involved in interspecific associations with several other organisms, including cnidarians, sponges, bryozoans, arthropods, annelids, molluscs, echinoderms, chordates, seaweeds and seagrasses (Gili and Hughes 1995; Boero and Bouillon 2005; Puce et al. 2008). In some cases, hydroids are obligatorily associated with their hosts, and these intimate associations are assumed to be achieved by the selectivity of hydrozoan larvae (e.g. Conover and Sieburth 1964; Piraino et al. 1994; Orlov 1997). In particular, the drivers of planula settlement of some hydroid species on specific hosts are known to be 
Publisher: CSIRO; Journal: IS:Invertebrate Systematics

Article Type: research-article; Volume: ; Issue: ; Article ID: IS16091

DOI: 10.1071/IS16091; TOC Head:

species-specific bacterial cues, such as for Hydractinia echinata (Fleming, 1828), for which the larval settlement and metamorphosis on gastropod shells inhabited by hermit crabs are regulated by Pseudoalteromonas espejiana (see Müller and Leitz 2002 for a review). Sponges are one of the most common hosts for hydrozoans (Puce et al. 2008), and associations may range from occasional to highly specific (Puce et al. 2005). To date, 26 hydrozoan species are known to live, at least partially, embedded by tissues of 28 species of sponges (Puce et al. 2005, 2008; Schuchert and Reiswig 2006; Brinckmann-Voss and Lindner 2008), whereas more than 100 species have been reported as occasional epibionts (Shimabukuro 2007). The specifically associated species show variable levels of integration with their sponge hosts: (i) hydranths grow into the canal system of the sponge; (ii) they protrude from the surface, but can retract into the host body; or (iii) they protrude from the surface and cannot retract into the sponge (Puce et al. 2005). The latter case is represented by the family Sphaerocorynidae Prévot, 1959, which has hydranths arising from the sponge surface, with the hydrorhiza embedded by host tissues. This family is composed of the two genera Sphaerocoryne Pictet, 1893 and Heterocoryne Wedler \& Larson, 1986. Although Sphaerocoryne is rarely found on other substrates, such as corals (Calder et al. 2003), coral rubble (Calder 2010), bivalves (Calder 1971), serpulid tubes (Galea 2008) and other hydrozoans (Mergner and Wedler 1977; Shimabukuro et al. 2006), both genera are considered obligate sponge-associated taxa, especially Heterocoryne, which is exclusively found on sponges (Wedler and Larson 1986; Galea 2013).

The family Sphaerocorynidae was erected by Prévot (1959), and formerly included only Sphaerocoryne, which had been assigned to Corynidae Johnston, 1836 by previous authors. Heterocoryne was later discovered by Wedler and Larson (1986), and was then assigned to the same family by Petersen (1990). Molecular analyses revealed that Sphaerocorynidae belongs to the clade Capitata sensu stricto, and it seems to be one of the basal taxa of the superfamily Zancleida (Nawrocki et al. 2010; Maggioni et al. 2016). However, the analysis of concatenated $16 \mathrm{~S}, 18 \mathrm{~S}$ and $28 \mathrm{~S}$ rRNA included only two Sphaerocoryne species and did not provide strong statistical support for their placement within Zancleida, due to either undersampling or the fact that no $18 S$ rRNA sequences were obtained for those species.

The taxonomic histories of most species of the family Sphaerocorynidae are confusing and the validity of some taxa still needs to be assessed. To date, four valid species belong to Sphaerocoryne, even though for two species, S. coccometra (Bigelow, 1909) and S. peterseni Bouillon, 1984, only the medusa stage is known (Bouillon 1984; Bigelow 1909). The remaining two species, S. agassizii (McCrady, 1859) and S. bedoti Pictet, 1893, show little morphological variation, and the diagnostic characters are mainly limited to the position of medusa buds on polyps, the arrangement of nematocysts in medusa buds, the number of tentacles, and the presence of ocelli in medusae at release (Calder 2010). Moreover, these two species were previously assigned to two genera (i.e. Corynetes Haeckel, 1879 and Sphaerocoryne, respectively) and Calder (2010) and Schuchert (2010) suggested retaining the two genera as distinct, at least until a molecular phylogeny clarifies their relationship. However, no conclusions on this issue have been drawn, due to the lack of precise knowledge of life cycles and morphology. Heterocoryne contains a single well-established species, $H$. caribbensis Wedler \& Larson 1986, whose morphological differences to Sphaerocoryne are clearly 
Publisher: CSIRO; Journal: IS:Invertebrate Systematics

Article Type: research-article; Volume: ; Issue: ; Article ID: IS16091

DOI: 10.1071/IS16091; TOC Head:

represented by the arrangement of tentacles and the reproductive structures (Wedler and Larson 1986;

Petersen 1990). Indeed, Sphaerocoryne is characterised by the presence of three to five whorls of capitate tentacles below the hypostome of the polyp, whereas Heterocoryne has a distal whorl of simple capitate tentacles and a proximal whorl of trifid capitate tentacles. Regarding the gonosome, Sphaerocoryne species reproduce via free-living medusae, whereas Heterocoryne bears gonophores reduced to single eumedusoids (Petersen 1990).

In this study, we describe the polyp and newly released medusa of a previously unknown species of Sphaerocorynidae collected from the Maldives and the Red Sea. By morphological and molecular analyses, the new species is assigned to a new genus, and the phylogenetic placement of the family within Zancleida is reconsidered using both mitochondrial and nuclear gene markers.

\section{Materials and methods}

Colonies of Sphaerocorynidae were collected during three separate field surveys conducted at St Eustatius, Dutch Caribbean, in June 2015, Thuwal, Saudi Arabian Red Sea in December 2015 and Magoodhoo Island, Faafu Atoll, Republic of Maldives in February 2016. Fragments of sponges associated with hydroids were sampled using plastic bags by SCUBA diving (maximum depth in all dives: $30 \mathrm{~m}$ ), and after dives were promptly placed in water tanks at the Reef Ecology Laboratory (King Abdullah University of Science and Technology, Saudi Arabia), the Marine Research and High Education (MaRHE) Center (Università degli Studi di Milano-Bicocca, Maldives) and the Caribbean Netherlands Science Institute (CNSI). Hydroid colonies were reared in laboratory to allow the release of medusae, which were cultivated for one week. Both polyps and newly released medusae were maintained in small oxygenated bowls at room temperature, and water was replaced daily. Samples were fixed in $6 \%$ or $10 \%$ formalin and in $99 \%$ ethanol for morphological and molecular characterisations, respectively. A Zeiss Axioskope 40 microscope was used to study the morphology of medusae and polyps, the latter after being carefully detached from their host under a Leica EZ4 D stereo microscope, using syringe needles and micropipettes. All pictures were taken with a Nikon AW100 camera, and measurements were obtained with an ocular micrometer. Drawings were made by hand based on photographs and were subsequently vectorised using CorelDRAW X7.

DNA from ethanol-preserved samples was extracted following a protocol modified from Zietara et al. (2000). Three molecular markers were amplified: a portion of the nuclear 28S rRNA ( 1700 bp) and $18 S$ rRNA ( 1700 bp), and a portion of the mitochondrial 16S rRNA ( 600 bp). The PCRs were set up using the same protocols and primers described in Maggioni et al. (2016), Medlin et al. (1988), and Cunningham and Buss (1993), respectively. All PCR products were purified and directly sequenced in forwards and reverse directions using an ABI 3730xl DNA Analyzer (Applied Biosystems, Foster City, CA, USA). The sequences obtained were deposited with the EMBL (GenBank accession numbers: LT714173-LT714187), and were aligned with other representatives of Zancleida and outgroups (Table 1), using MAFFT 7.110 (Katoh and Standley 2013) with the E-INS-i option. The obtained alignments were run through Gblocks (Castresana 2000; Talavera and Castresana 2007) to remove ambiguously aligned regions, using the default 'less 
Publisher: CSIRO; Journal: IS:Invertebrate Systematics

Article Type: research-article; Volume: ; Issue: ; Article ID: IS16091

DOI: 10.1071/IS16091; TOC Head:

stringent' settings. The sequences were combined into a concatenated dataset and PartitionFinder 1.1.1

(Lanfear et al. 2012) was used to determine the partition scheme and the molecular models. Bayesian inference (BI) and maximum likelihood (ML) were used to infer phylogenetic relationships of both multiand single-locus datasets. Bayesian inference analyses were performed using MrBayes 3.2 (Ronquist et al. 2012). Four parallel Markov chain Monte Carlo (MCMC) runs were carried out for $3 \times 10^{6}$ generations. Trees were sampled every 100th generation, and burn-in was set to $25 \%$. Maximum likelihood trees were built with Garli 2.01 (Zwickl 2006) and read into the SumTrees 4.0.0 program in the DendroPy 4.0.0 package (Sukumaran and Holder 2010) to calculate non-parametric bootstrap support (BS) values from 1000 replicates, each based on five heuristic search replicates, and to map them on the best ML tree. Bayesian posterior probabilities (BPP) and BS values were indicated at each node. The genetic distances (uncorrected p-distance, 1000 bootstrap replicates) between samples from the Red Sea and the Maldives were also estimated using MEGA6 (Tamura et al. 2013).

Type material of the new species was deposited at Museo Civico di Storia Naturale di Milano (MSNM), Milan, Italy.

\section{Results}

\section{Phylogenetic analyses}

The total alignment of the concatenated 16S-18S-28S dataset was 4006 bp long (3876 bp long after Gblock treatment), and included representatives of all the main families belonging to Capitata. The general topology of the phylogenetic trees based on BI and ML analyses were almost identical, and therefore only the Bayesian topology is shown (Fig. 1). Nuclear single-locus analyses recovered highly concordant topologies, whereas $16 \mathrm{~S}$ analysis showed less resolution at deeper nodes.

The overall statistical support of the tree is higher in the concatenated analysis, with most nodes supported by BPP > 0.95 or BS > 75 or both, and we therefore consider it as our most robust phylogenetic hypothesis. Our results are concordant with previous works (Nawrocki et al. 2010; Maggioni et al. 2016), recovering the superfamily Zancleida as a monophyletic lineage, with the clade composed of Pennariidae and Hydrocorynidae being the sister group of the remaining families. All our specimens of Astrocoryne cabela, gen. et sp. nov. form a fully supported monophyletic clade that clusters with Sphaerocoryne spp. and Heterocoryne caribbensis, constituting the family Sphaerocorynidae. This family diverged early from the other taxa of Zancleida, just after the Pennariidae-Hydrocorynidae group. Moreover, the addition of new taxa and newly obtained $18 S$ sequences of Sphaerocoryne sp. to the dataset improved the statistical support of this node. All the specimens of $A$. cabela share the same nuclear haplotypes for both $18 S$ and $28 S$ loci, whereas $16 S$ sequences of samples from the Red Sea and the Maldives are slightly divergent, with a genetic distance of $1.1( \pm 0.5) \%$. 


\section{Systematics}

According to the morphological features and phylogenetic placement described in 'Phylogeny', we describe a new species and genus of hydrozoan belonging to the family Sphaerocorynidae.

\section{Phylum CNIDARIA Verril}

\section{Class HYDROZOA Owen}

\section{Order ANTHOATHECATA Cornelius}

\section{Family SPHAEROCORYNIDAE Prévot}

\section{Amended diagnosis \\ Polyp stage}

Colonies either stolonal or erect; hydrorhiza creeping; hydrocauli long, unbranched or sparingly branched, with terminal hydranths; perisarc thin, reaching hydranth base or stopping at the insertion with the hydrorhiza; hydranth pyriform, with bulbous base and proboscis-like hypostome; no oral tentacles, but single, trifid or dicapitate tentacles in one to five whorls around broadest part of body; gonophores arising above or among tentacles as free medusae or sessile eumedusoids.

\section{Medusa stage}

Eumedusoid or free medusa with thick bell-shaped or conical umbrella; apical projection, when present, conical or dome-shaped, with thick mesoglea and broad apical chamber; manubrium flask-shaped, quadrate, or cruciform, narrowing towards the mouth, the latter simple, round or cruciform; two or four tentacles with adaxial, evenly distributed, spirally arranged or absent nematocyst clusters, with a terminal, ellipsoid or spherical capitation; marginal bulbs large, clasping exumbrella, each with adaxial expansion; ocelli abaxial, not always present in newly liberated medusae; gonads adradial, confluent in perradii in mature specimens.

\section{Remarks}

The diagnosis of the family Sphaerocorynidae is broadened by adding the unique characteristics (i.e. tentacles in hydroids and medusae) of $A$. cabela. The family now includes three valid genera: Sphaerocoryne, Heterocoryne and Astrocoryne, gen. nov. Heterocoryne and Astrocoryne are monotypic genera, whereas Sphaerocoryne includes S. agassizii, S. peterseni, S. coccometra and S. bedoti, the latter being the type species of the family.

Genus Astrocoryne, gen. nov.

(Figs 2-4)

http://zoobank.org/urn:lsid:zoobank.org:act:XXX 
Publisher: CSIRO; Journal: IS:Invertebrate Systematics

Article Type: research-article; Volume: ; Issue: ; Article ID: IS16091

DOI: 10.1071/IS16091; TOC Head:

Diagnosis

Polyp stage

Hydroid forming stolonal colonies; hydrocaulus short to moderately long, simple, arising from a hydrorhiza embedded in tissue of host sponge; perisarc thin, covering both the hydrorhiza and the hydrocaulus; hydranth slightly pyriform, with dicapitate tentacles in one or two alternating whorls around broadest part of the body; hypostome proboscis-like, contractile; gonophores developing among tentacles on short blastostyles.

\section{Medusa stage}

Newly liberated medusae with bell-shaped umbrella and scattered nematocysts on exumbrella; four tentacular bulbs, two of which bear an opposite tentacle, with a terminal spherical knob of nematocysts; manubrium cylindrical, with circular mouth.

\section{Remarks}

The genus Astrocoryne, gen. nov. differs from Sphaerocoryne according to the arrangement of tentacles in polyps and to the type of tentacles in both polyps and medusae. Unlike Astrocoryne, Heterocoryne bears fixed gonophores, and the proximal parts of the tentacles are partially fused in superimposed groups of three, only their distal parts remaining free from each other (see Table S1, available as supplementary material to this paper, for main diagnostic characters for all sphaerocorynid species). The genus Bibrachium Stechow, 1919, a poorly known sponge-associated hydroid, has two opposite capitate tentacles with an adoral cluster of nematocysts just below the terminal capitation (Schulze 1880), the latter feature being similar to Astrocoryne. However, in Bibrachium, the cluster of nematocysts below the capitation is restricted to the adoral side, the polyp has only two tentacles, and there is no information regarding its reproduction. The genus Tricyclusa Stechow, 1919 has tentacles similar to those of Astrocoryne, but the proximal cluster of nematocysts is often incomplete and, in some cases, three intermediate clusters, besides the terminal one, can be found (Vervoort 1949), thus resembling imperfect moniliform tentacles.

Regarding the medusa stage, Astrocoryne is similar to Dicnida Bouillon, 1978, in having a simple mouth, four bulbs, two opposed tentacles with a terminal knob of nematocysts, and an identical cnidome. However, Dicnida has a prominent apical projection also in juveniles, the manubrium is quadrate, tentacles are (exceedingly) long and particularly rigid and, in some cases, bear halfway secondary ramifications, each with its own terminal capitation, non-tentaculate bulbs are extending on the exumbrella, and both the polyp stage and the size and shape of nematocysts are not known (Bouillon 1978). Consequently, Astrocoryne is established here as a distinct new genus.

\section{Etymology}

Astrocoryne derives from the combination of the Ancient Greek ó $\sigma \tau \hat{\jmath} \rho$ ('aster'), meaning star and referring to the star-shaped aspect of the hydranth, and Coryne, following the structure of names of the other two genera ascribed to Sphaerocorynidae. It is a feminine noun. 
Publisher: CSIRO; Journal: IS:Invertebrate Systematics

Article Type: research-article; Volume: ; Issue: ; Article ID: IS16091

DOI: 10.1071/IS16091; TOC Head:

Astrocoryne cabela, gen. et sp. nov.

(Figs 2-4)

\section{http://zoobank.org/urn:Isid:zoobank.org:act:XXX}

\section{Material examined}

Holotype. Sample MA16053, Maldives: Magoodhoo Island, Faafu Atoll, 34"1.2"N, 72 $57^{\prime} 0^{\prime \prime} \mathrm{E}$, depth $25 \mathrm{~m}$, 8.ii.2016, fertile colony growing on Clathria sp. sponge, preserved in $99 \% \mathrm{EtOH}$ [ethanol] and 10\% formalin, MSNMCoe341.

Paratype. $\quad$ Sample MA16053, Maldives: Magoodhoo Island, Faafu Atoll, 34'1.2"N, 7257'0"E, 8.ii.2016, two-day-old medusae collected from parental colony (MSNMCoe341) and reared at the MaRHE Center in Magoodhoo Island, preserved in $10 \%$ formalin, MSNMCoe 342.

Other material. Sample MA16052, Maldives: Magoodhoo Island, Faafu Atoll, 34'1.2"N, 7257'0"E, depth 12 m, 8.ii.2016, colony growing on Haliclona sp. sponge, preserved in 99\% EtOH and 6\% formalin. Sample KA175, Saudi Arabia: Shark reef, Thuwal, Red Sea, 22 ${ }^{\circ} 25^{\prime} 1.2^{\prime \prime} \mathrm{N}, 38^{\circ} 58^{\prime} 58.8^{\prime \prime}$ E, depth 18 m, 17.xii.2015, colony growing on an unidentified tube sponge, preserved in $99 \% \mathrm{EtOH}$.

\section{Diagnosis}

Same as for the genus.

\section{Description}

\section{Polyp stage}

Colonies monomorphic, living in association with different sponges (Fig. $2 A-C$ ). Hydrorhiza tubular, branched, $50-65 \mu \mathrm{m}$ in diameter, covered by moderately thick and slightly wrinkled perisarc (3-6 $\mu \mathrm{m}$ thick) (Fig. 2G), embedded by sponge tissues and giving rise to several hydranths. Pedicels short $(90-190 \mu \mathrm{m})$ in Maldivian specimens to moderately long $(450-580 \mu \mathrm{m})$ in specimens from the Red Sea, unbranched, covered by a smooth, thin $(1-2 \mu \mathrm{m})$, cup-shaped or elongated perisarc (Fig. $2 G, H$ ), with a diameter at the distal portion of 50-100 $\mu \mathrm{m}$. Hydranth slightly pyriform, up to $0.8 \mathrm{~mm}$ long, with variable diameter (90-100 $\mu \mathrm{m}$ at the base; $200-240 \mu \mathrm{m}$ at the tentacle-bearing portion; 60-70 $\mu \mathrm{m}$ at the base of hypostome). Hypostome proboscis-like, contractile, 200-400 $\mu \mathrm{m}$ long and 60-100 $\mu \mathrm{m}$ thick, with a distal circular mouth (Figs 2D, $4 A, B)$. Up to 10 tentacles (generally 8-10) arranged in either one (specimens from the Maldives) or two close whorls (specimens from the Red Sea) in the broadest part of the polyp (Figs 2D, 4A, B). Each tentacle with a terminal, nematocyst-rich capitation (diameter: 50-85 $\mu \mathrm{m}$ in the distal whorl; $25-30 \mu \mathrm{m}$ in the proximal whorl) and another, sub-terminal, spherical cluster of nematocysts (diameter: $70-110 \mu \mathrm{m}$ in the distal whorl; 35-45 in the proximal whorl) (Fig. 2E). Tentacles around $500 \mu \mathrm{m}$ long $(350-530 \mu \mathrm{m})$ in the distal whorl, shorter in the proximal whorl $(200-320 \mu \mathrm{m})$ when present. Nematocyst clusters $\sim 100 \mu \mathrm{m}$ distant from one other, moved closer by the contraction of the distal part of tentacles (Fig. $2 F$ ). Up to 11 medusa buds at different stages of maturation develop among tentacles (Fig. 2I), singly or in couple on blastostyles up to $100 \mu \mathrm{m}$ long (Fig. 21J). Living hydranths transparent, with white mouths and whitish or light orange gastric cavities (Fig. $2 A-C$ ). Nematocysts of all types occurring simultaneously and 
Publisher: CSIRO; Journal: IS:Invertebrate Systematics

Article Type: research-article; Volume: ; Issue: ; Article ID: IS16091

DOI: 10.1071/IS16091; TOC Head:

concentrated in the terminal and proximal capitations, as well as scattered in the hydrorhiza, more rarely in the hydranth. Cnidome: desmonemes (undischarged: 7-9 $\times 4-5 \mu \mathrm{m}$; discharged capsule: 6-8 8 4-5 $\mu \mathrm{m}$; shaft: $5 \times 5 \mu \mathrm{m}$, coiling three times) (Figs $2 K, 4 H$ ); microbasic euryteles (undischarged: $13-15 \times 5-6 \mu \mathrm{m}$; discharged capsule: 10-12 × 4-5 $\mu \mathrm{m}$; shaft: 9-11 $\mu \mathrm{m})$ (Figs 2L, 4I); large stenoteles (undischarged: 18-21 × 13-17 $\mu \mathrm{m}$; discharged capsule: 15-18 × 11-15 $\mathrm{m}$ ) (Figs 2M, 4D); medium-sized stenoteles (undischarged:

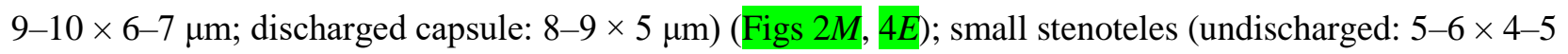
$\mu \mathrm{m}$; discharged capsule: $5 \times 4-5 \mu \mathrm{m})($ Figs $2 M, 4 F)$.

\section{Medusa stage}

Newly liberated medusa hemispherical, 460-500 $\mu \mathrm{m}$ wide and 480-500 $\mu \mathrm{m}$ high, with a velar opening of 300-350 $\mu \mathrm{m}$, and with nematocysts scattered on the exumbrella (Figs 2A, B, 3C). A short protrusion on the apical part of the exumbrella might result from liberation from the blastostyle (Fig. 3C). Manubrium cylindrical, 150-200 $\mu \mathrm{m}$ long and 80-110 wide at the base, spanning from one-third to half of the bell height, distally provided with a circular mouth (diameter 50-75 $\mu \mathrm{m}$ ), with no additional oral structures and no incipient gonads (Fig. 3B,C). Four radial canals end in four bulbs with a diameter of 60-70 $\mu \mathrm{m}$, linked by a circular canal (Fig. 3D). Both bulbs and circular canal contain nematocysts. When released, medusae with no tentacles, but all bulbs show swellings filled with nematocysts (Fig. 3A). Two days after release, medusae with two opposite tentacles (Fig. 3B,D). Tentacles up to $300 \mu \mathrm{m}$ long, armed with terminal spherical nematocyst-rich capitations with diameter 70-85 $\mu \mathrm{m}$ (Fig. 3E, F). Ocelli not present at release. Nematocysts scattered on the exumbrella (microbasic mastigophores and rarely microbasic euryteles similar to those found in polyps), in the circular canal (stenoteles), in the bulb swellings and in the terminal capitations of tentacles (stenoteles and desmonemes). Cnidome: microbasic euryteles (undischarged: $14 \times 5 \mu \mathrm{m})($ Fig. $3 G$, 3I); microbasic mastigophores (undischarged: 6-7 6 5-7 $\mu \mathrm{m}$; discharged capsule: $5 \times 5 \mu \mathrm{m}$; shaft: $5 \mu \mathrm{m}$ ) (Figs 3H, 4G); stenoteles $(9-11 \times 8-10 \mu \mathrm{m}$; discharged capsule: $8-9 \times 7 \mu \mathrm{m})$ (Figs 3I, 4E); desmonemes (undischarged: 7-8 $\times 4-5 \mu \mathrm{m}$; discharged capsule: $6 \times 4 \mu \mathrm{m}$; shaft: $5 \times 5 \mu \mathrm{m}$, coiling three times) (Figs $3 J$, $4 H)$.

\section{Relationship with the host, habitat and distribution}

Astrocoryne cabela, gen. et sp. nov. was found in association with three different sponges: Haliclona sp., Clathria sp. and an unidentified tube sponge. However, specimens of these sponges were found at the same areas and depths with no associated hydroids. The hydrozoan colonies occupied in all cases a small area of the sponges and the polyps were distributed with no apparent spatial preferences on the host. Slight differences were noticed in the reaction of sponges to the presence of hydroids: Clathria sp. surrounds the base of the polyps forming a cone-shaped collar (Fig. 2A), whereas Haliclona sp. and the tube sponge show no apparent modifications (Fig. 2B, C). Interestingly, the material from the Red Sea shared the sponge host with a colony of Sphaerocoryne sp., for which the identification to species level was not possible due to the lack of reproductive structures. Astrocoryne cabela was observed between 12 and $25 \mathrm{~m}$ depth, although deeper or shallower distribution limits cannot be excluded. The known geographic distribution is limited to the central Red Sea (Thuwal) and to the central Maldives (Faafu Atoll). 


\section{Remarks}

Astrocoryne cabela from the Red Sea and the Maldives shows variation in the arrangement of tentacles and in the length of the pedicel (Table 2). Specimens from the Maldives have one whorl of tentacles, whereas polyps from the Red Sea have two whorls of tentacles, the proximal one being shorter and provided with smaller nematocyst knobs. However, they both share the apomorphy of having a proximal cluster of nematocyst in all tentacles and we named this new type of tentacle 'dicapitate'. The perisarc in Maldivian specimens stops at the base of polyps, resulting in a short pedicel, while in the Red Sea samples the pedicel is longer and the perisarc almost reaches the proximal whorl of tentacles. As the colonies found in the Red Sea were not fertile, the medusa was not observed, leaving uncertainties about other possible morphological differences in the two populations in this life-cycle stage. The Maldivian medusae developed two opposite tentacles two days after their release and were cultivated for a total of seven days, during which they did not show any further morphological variation. However, we cannot exclude that the adult medusa might develop four tentacles, similarly to what happens in Sphaerocoryne agassizii (McCrady 1859) and further surveys are needed to describe the morphology of mature medusae and fully characterise the life cycle of this species.

\section{Etymology}

The species name cabela refers to the name of the house where the parents of DM live, in recognition of their support over the years.

\section{Discussion}

Sponges provide habitat for a large number of species belonging to several taxa (Wulff 2006), and due to the richness of their associated fauna, they have been called 'living hotels' (Pearse 1950). Many of the associated organisms live inside the canal system, where they can find food and shelter (Tyler and Böhlke 1972; Rützler 1978), whereas others live epibiontically on their outer surface, where, for instance, they might benefit from the water renewal generated by the sponge itself (e.g. Uriz et al. 1992). Only two species of hydrozoans are known to live as sponge endosymbionts and correspond to Bibrachium euplectellae (Schulze, 1880) and Brinckmannia hexactinellidophila Schuchert \& Reiswig, 2006, both associated with hexactinellid sponges (Schulze 1880; Schuchert and Reiswig 2006). However, most of the sponge-associated hydrozoans can be considered as partial endosymbionts, as their hydrorhizae are surrounded by the host and the hydranths protrude from sponge tissues (Puce et al. 2005). The families Tubulariidae Goldfuss, 1818, Corynidae and Sphaerocorynidae contain the highest number of sponge-associated species, but only the latter is known to have all its members specifically associated with sponges (Puce et al. 2005). This idea is confirmed by the description of Astrocoryne, which was exclusively found in association with sponges. The hydroids of A. cabela were clearly assignable to Sphaerocorynidae due to their morphology and, in particular, to the pyriform shape of the hydranth, the proboscis-like hypostome and the tentacles arranged in one or a few whorls below the hypostome, among which the gonophores arise. However, this species shows an apomorphy, represented by the peculiar type of tentacles that necessitated creation of a new genus. Additionally, molecular phylogenetic analyses confirmed the position of this species within 
Publisher: CSIRO; Journal: IS:Invertebrate Systematics

Article Type: research-article; Volume: ; Issue: ; Article ID: IS16091

DOI: 10.1071/IS16091; TOC Head:

Sphaerocorynidae and showed a high genetic divergence from Sphaerocoryne species and Heterocoryne caribbensis, supporting the establishment of a new genus.

The type of tentacles represents one of the main differences among the hydranths belonging to different genera of Sphaerocorynidae (Petersen 1990) (Fig. 5; Table S1), and both Astrocoryne and Heterocoryne bear apomorphic tentacles. In Sphaerocoryne, the tentacles are simple capitate (Fig. 5A) and, in some cases, have been reported as grouped in longitudinal rows (Yamada and Konno 1973). Tentacles of the proximal whorl in $H$. caribbensis consist of three capitate tentacles partially fused longitudinally in their proximal halves, but still showing their own rows of endodermal cells (Fig. 5B) (Wedler and Larson 1986; Galea 2013), slightly resembling the ramified capitate tentacles of Cladocoryne Rotch, 1871, the latter having nevertheless the endoderm of the axis of tentacle and ramifications fused (Prévot 1959). Finally, A. cabela has capitate tentacles with a proximal cluster of nematocysts resembling a halfway capitulum (Fig. 5C). According to Prévot (1959), the most ancestral state of tentacles is represented by a nematocyst button, followed by the capitate tentacle, and all other types of tentacles evolved from this condition. Following this classification, Sphaerocoryne has the most ancestral tentacles among Sphaerocorynidae, having all capitate tentacles, whereas Astrocoryne and Heterocoryne have more derived tentacles. The double capitation in Astrocoryne polyps may derive from a duplication event in the proximal-distal axis of tentacles (Fig. 6). Less-regulated duplication events may be responsible for other peculiar tentacles, such as those of Tricyclusa singularis (Schulze, 1876), and repeated events may be the explanation for moniliform tentacles. The unique condition of proximal tentacles in Heterocoryne polyps may be either the result of partial duplication events along the mid-later axis of capitate tentacles or the partial fusion of already divided tentacles (Fig. 6). Therefore, detailed histological analyses, as well as the study of the expression patterns of homeotic genes involved in the development of tentacles, are needed to shed light on the evolution of tentacles in both sphaerocorynid and other capitate hydrozoans.

The association between hydroids and their hosts is usually constant (Puce et al. 2005) and, in some cases, molecular analyses demonstrated that hydrozoan species associated with different hosts actually constitute species complexes, with different molecular groups associated with specific hosts (Montano et al. 2015, 2017; Maggioni et al. 2016). Sphaerocorynid polyps have been mostly reported growing on unidentified sponges, and only in few cases the identification of the host, at least at genus level, was provided. In particular, Sphaerocoryne bedoti is known to be associated with at least nine sponge genera and as many species (Calder 1971; Yamada and Konno 1973; Wedler and Larson 1986; Varela 2012), whereas $H$. caribbensis has been reported so far to live in association with sponges probably belonging to the genus Mycale Gray, 1867 (Wedler and Larson 1986) (see Table S1 for known sponge hosts). Throughout our surveys, we found A. cabela on three different sponges and, in one case, we recorded it as sharing the same sponge host together with a colony of Sphaerocoryne, suggesting that the former species could be a generalist symbiont of poriferans. Therefore, according to the literature and our results, hydrozoans ascribed to Sphaerocorynidae do not seem to have evolved species-specific relationships with their hosts, although further in-depth multi-disciplinary analyses of these associations are needed to address this question. For 
Publisher: CSIRO; Journal: IS:Invertebrate Systematics

Article Type: research-article; Volume: ; Issue: ; Article ID: IS16091

DOI: 10.1071/IS16091; TOC Head:

instance, sponge-associated micro-organisms may have a role in the settlement and metamorphosis of sphaerocorynid planulae, similarly to what happens for instance for Hydractinia echinata (Müller and Leitz 2002), and microbiome-related studies may help identifying specific shared microbial components among different sponges.

The analysed specimens of $A$. cabela from the Red Sea and the Maldives showed some morphological differences in the polyp stage, that is, the length of the pedicel and the number of tentacle whorls, and these variations might normally be marked enough to allow the distinction of the samples from the two localities as two distinct species. Nevertheless, according to the molecular analyses, all samples show only a slight genetic divergence that can be observed solely in the mitochondrial marker, and that is likely to be due to the geographic distance other than a speciation event. These differences seem therefore to be better explained by intra-specific morphological variation, a common phenomenon in hydrozoans that can be related to environmental conditions and ontogeny (Cunha et al. 2016). It is likely that unexplored biotic and abiotic ecological factors might contribute, synergistically or not, to the observed morphological variation. For instance, differences in hydranths might be related to salinity (e.g. Kinne 1957; Kinne and Paffenhöfer 1965), which differs by about five psu between the two sampling localities (Reimer et al. 2017; Seveso et al. 2017), and variations in the pedicel might be due to distinct reactions of the polyps to different hosts. However, the Red Sea is known to be a hotspot of biodiversity and endemism (Hughes et al. 2002), and is characterised by a peculiar geological history and several barriers (see DiBattista et al. 2016 for a review) that might be responsible for ongoing speciation between populations from the Maldives and Saudi Arabia. Astrocoryne cabela is likely to be present also in other localities in the Red Sea and in the Indo-Pacific, and both the inclusion of other geographic areas in the molecular analyses and the morphological study of all life stages for all populations may clarify the diversity and genetic structure of this hydroid. Finally, a comprehensive molecular and morphological appraisal of the whole Sphaerocorynidae family is necessary to clarify the taxonomic problems of all species and genera, and to assess the diversity, biogeography and evolution of these often reported, but poorly known, hydrozoans.

\section{Acknowledgements}

The authors are indebted to Tullia Terraneo and Malek Amr Gusti from Reef Ecology Laboratory (KAUST), Bert W. Hoeksema from Naturalis Biodiversity Center, and Enrico Montalbetti from Università degli Studi di Milano-Bicocca for logistic support and field assistance. The authors are very grateful to Stefano Piraino, Horia Galea and one anonymous reviewer, whose valuable comments greatly improved the manuscript. Permission to undertake the research has been obtained from the applicable governmental agencies in the investigated areas. This project was supported by funding from KAUST (award \# URF/1/1389-01-01 and baseline research funds to MLB), from Università degli Studi di Milano-Bicocca (baseline research funds to PG) and from PADI Foundation, USA (Grant \#14384). Fieldwork participation of SM to Statia Marine Biodiversity Expeditiona to St Eustatius was funded through a Martin Fellowship from Naturalis Biodiversity Center. 
Publisher: CSIRO; Journal: IS:Invertebrate Systematics

Article Type: research-article; Volume: ; Issue: ; Article ID: IS16091 DOI: 10.1071/IS16091; TOC Head:

\section{References}

<jrn>Bigelow, H. B. (1909). The Medusae. Reports on the scientific results of the expedition to the eastern tropical pacific, in charge of Alexander Agassiz, by the U.S. Fish Commission steamer 'Albatross' from October, 1904, to March, 1905. Memoirs of the Museum of Comparative Zoology at Harvard College 37, 1-243.</jrn>

<edb>Boero, F., and Bouillon, J. (2005). Cnidaria and Ctenophora. In ‘Marine Parasitology'. (Ed. K. Rohde.) pp. 177-

182. (CSIRO Publishing: Collingwood, Australia.) $</$ edb $>$

<jrn>Bouillon, J. (1978). Hydroméduses de la Mer de Bismarck (Papouasie, Nouvelle-Guinée). Partie 1: Anthomedusae Capitata (Hydrozoa - Cnidaria). Cahiers de Biologie Marine 19, 249-297. [In French]</jrn>

<jrn>Bouillon, J. (1984). Sphaerocoryne peterseni: nouvelle espèce d'Anthoméduse de la Papouasie Nouvelle-Guinée. Indo-Malayan Zoology 1, 245-248.</jrn>

<jrn>Brinckmann-Voss, A., and Lindner, A. (2008). Monocoryne colonialis sp. nov., a colonial candelabrid hydroid (Cnidaria: Hydrozoa: Candelabridae) from the North Pacific. Journal of the Marine Biological Association of the United Kingdom 88, 1631-1635. doi:10.1017/S002531540800180X </jrn>

<other>Calder, D. (1971). Hydroids and hydromedusae of southern Chesapeake Bay. Virginia Institute of Marine Science. Special Papers in Marine Science 1, 1-125.</other>

$<$ jrn>Calder, D. R. (2010). Some anthoathecate hydroids and limnopolyps (Cnidaria, Hydrozoa) from the Hawaiian archipelago. Zootaxa 2590, 1-91.</jrn>

<jrn>Calder, D. R., Mallinson, J. J., Collins, K., and Hickman, C. P. (2003). Additions to the hydroids (Cnidaria) of the Galápagos, with a list of species reported from the islands. Journal of Natural History 37, 1173-1218. doi:10.1080/00222930110116039</jrn>

<jrn>Castresana, J. (2000). Selection of conserved blocks from multiple alignments for their use in phylogenetic analysis. Molecular Biology and Evolution 17, 540-552. doi:10.1093/oxfordjournals.molbev.a026334</jrn>

$<$ jrn>Conover, J. T., and Sieburth, J. M. (1964). Effect of Sargassum distribution on its epibiota and antibacterial activity. Botanica Marina 6, 147-157. doi:10.1515/botm.1964.6.1-2.147</jrn>

<jrn>Cornelius, P. F. (1992). Medusa loss in leptolid Hydrozoa (Cnidaria), hydroid rafting, and abbreviated life-cycles among their remote-island faunae: an interim review. Scientia Marina 56, 245-261.</jrn>

$<$ jrn>Cunha, A. F., Maronna, M. M., and Marques, A. C. (2016). Variability on microevolutionary and macroevolutionary scales: a review on patterns of morphological variation in Cnidaria Medusozoa. Organisms, Diversity \& Evolution 16, 431-442. doi:10.1007/s13127-016-0276-4</jrn>

<jrn>Cunningham, C. W., and Buss, L. W. (1993). Molecular evidence for multiple episodes of paedomorphosis in the family Hydractiniidae. Biochemical Systematics and Ecology 21, 57-69. doi:10.1016/0305-1978(93)90009-G</jrn> <bok>Fleming, J. A. (1828). 'History of British Animals.' (Bell and Bradfute: Edinburgh, UK.)</bok>

$<j r n>$ Fraser, C. M. (1938). Hydroids of the 1934 Allan Hancock Pacific Expedition. Allan Hancock Pacific Expeditions 4, 1-105. </jrn>

$<$ jrn>Galea, H. R. (2008). On a collection of shallow-water hydroids (Cnidaria: Hydrozoa) from Guadeloupe and Les Saintes, French Lesser Antilles. Zootaxa 1878, 1-54.</jrn> 
Publisher: CSIRO; Journal: IS:Invertebrate Systematics

Article Type: research-article; Volume: ; Issue: ; Article ID: IS16091

DOI: 10.1071/IS16091; TOC Head:

$<$ jrn>Galea, H. R. (2013). New additions to the shallow-water hydroids (Cnidaria: Hydrozoa) from the French Lesser

Antilles: Martinique. Zootaxa 3686, 1-50. doi:10.11646/zootaxa.3686.1.1</jrn>

<jrn>Gili, J. M., and Hughes, R. G. (1995). The ecology of marine benthic hydroids. Oceanography and Marine

Biology 33, 351-426.</jrn>

<jrn>Goldfuss, G. A. (1818). Ueber die Classification der Zoophyten. Isis 1818, 1008-1013.</jrn>

$<$ jrn>Gray, J. E. (1867). Notes on the arrangement of sponges, with the descriptions of some new genera. Proceedings of the Zoological Society of London 2, 492-558.</jrn>

<bok>Haeckel, E. (1879). 'Das System der Medusen. Erster Teil einer Monographie der Medusen.' (Denkschriften der Medicinisch-Naturwissenschaftlichen Gesellschaft: Jena, Germany.)</bok>

<jrn>Johnston, G. (1836). A catalogue of the zoophytes of Berwickshire. History of the Berwickshire Naturalists' Club

1, 107-108.</jrn>

<jrn>Katoh, K., and Standley, D. M. (2013). MAFFT multiple sequence alignment software version 7: improvements in performance and usability. Molecular Biology and Evolution 30, 772-780. doi:10.1093/molbev/mst010</jrn>

<jrn>Kinne, O. (1956). Über den einfluß des salzgehaltes und der temperatur auf wachstum, form und vermehrung bei

dem hydroidpolypen Cordylophora caspia (Pallas), Athecata, Clavidae. Zoologische Jahrbucher. Abteilung fur

Allgemeine Zoologie und Physiologie der Tiere 66, 565-638. </jrn>

<jrn>Kinne, O., and Paffenhöfer, G. A. (1965). Hydranth structure and digestion rate as a function of temperature and salinity in Clava multicornis (Cnidaria, Hydrozoa). Helgoländer Wissenschaftliche Meeresuntersuchungen 12, 329 341. doi:10.1007/BF01612558</jrn>

<jrn>Lanfear, R., Calcott, B., Ho, S. Y., and Guindon, S. (2012). PartitionFinder: combined selection of partitioning schemes and substitution models for phylogenetic analyses. Molecular Biology and Evolution 29, 1695-1701.

doi:10.1093/molbev/mss020</jrn>

<jrn>Maggioni, D., Montano, S., Seveso, D., and Galli, P. (2016). Molecular evidence for cryptic species in Pteroclava krempfi (Hydrozoa, Cladocorynidae) living in association with alcyonaceans. Systematics and Biodiversity 14, 484 493. doi:10.1080/14772000.2016.1170735</jrn>

<jrn>McCrady, J. (1859). Gymnopthalmata of Charleston harbor. Proceedings of the Elliot Society of Natural History

1, 103-221.</jrn>

<jrn>Medlin, L., Elwood, H. J., Stickel, S., and Sogin, M. L. (1988). The characterization of enzymatically amplified eukaryotic 16S-like rRNA-coding regions. Gene 71, 491-499. doi:10.1016/0378-1119(88)90066-2. </jrn>

<jrn>Mergner, H., and Wedler, E. (1977). Ueber die hydropolypenfauna des Roten Meeres und seiner ausgänge. Meteor Forschungsergebnisse 24, 1-32.</jrn>

<jrn>Montano, S., Maggioni, D., Arrigoni, R., Seveso, D., Puce, S., and Galli, P. (2015). The hidden diversity of

Zanclea associated with scleractinians revealed by molecular data. PLoS One 10, e0133084.

doi:10.1371/journal.pone.0133084</jrn> 
Publisher: CSIRO; Journal: IS:Invertebrate Systematics

Article Type: research-article; Volume: ; Issue: ; Article ID: IS16091

DOI: 10.1071/IS16091; TOC Head:

<jrn>Montano, S., Maggioni, D., Galli, P., and Hoeksema, B. W. (2017). A cryptic species in the Pteroclava krempfi species complex (Hydrozoa, Cladocorynidae) revealed in the Caribbean. Marine Biodiversity 47, 83-89.

doi:10.1007/s12526-016-0555-5</jrn>

<jrn>Müller, W. A., and Leitz, T. (2002). Metamorphosis in the Cnidaria. Canadian Journal of Zoology 80, $1755-1771$. doi:10.1139/z02-130</jrn>

<jrn>Nawrocki, A. M., Schuchert, P., and Cartwright, P. (2010). Phylogenetics and evolution of Capitata (Cnidaria: Hydrozoa), and the systematics of Corynidae. Zoologica Scripta 39, 290-304. doi:10.1111/j.1463$\underline{6409.2009 .00419 . x}</ j r n>$

<jrn>Orlov, D. V. (1997). The role of larval settling behaviour in determination of the specific habitat of the hydrozoan Dynamena pumila (L.). Larval settlement in Dynamena pumila (L.). Journal of Experimental Marine Biology and Ecology 208, 73-85. doi:10.1016/S0022-0981(96)02673-1</jrn>

<bok>Owen, R. (1843). 'Lectures on the Comparative Anatomy and Physiology of the Invertebrate Animals, Delivered at the Royal College of Surgeons in 1843 From Notes Taken by William White Cooper, M. R. C. S. and Revised by Professor Owen.' (Longman, Brown, Green and Longmans: London, UK.) </bok>

<jrn>Pearse, A. S. (1950). Notes on the inhabitants of certain sponges at Bimini. Ecology 31, 149-151. doi:10.2307/1931369</jrn>

<jrn>Petersen, K. W. (1990). Evolution and taxonomy in capitate hydroids and medusae (Cnidaria: Hydrozoa). Zoological Journal of the Linnean Society 100, 101-231. doi:10.1111/j.1096-3642.1990.tb01862.x</jrn>

<jrn>Pictet, C. (1893). Étude sur les hydraires de la Baie d'Amboine. Revue Suisse de Zoologie 1, 1-64. doi:10.5962/bhl.part.3743 $</$ jrn $>$

<jrn>Piraino, S., Todaro, C., Geraci, S., and Boero, F. (1994). Ecology of the bivalve-inhabiting hydroid Eugymnanthea inquilina in the coastal sounds of Taranto (Ionian Sea, SE Italy). Marine Biology 118, 695-703. doi:10.1007/BF00347518</jrn>

<other>Prévot, E. (1959). Morphologie et évolution des structures tentaculaires chez les hydraires gymnoblastes Capitata. Recueil des Travaux de la station marine d'Endoume 29, 91-128.</other>

<jrn>Puce, S., Calcinai, B., Bavestrello, G., Cerrano, C., Gravili, C., and Boero, F. (2005). Hydrozoa (Cnidaria) symbiotic with Porifera: a review. Marine Ecology (Berlin) 26, 73-81. doi:10.1111/j.1439-0485.2005.00050.x</jrn>

<jrn>Puce, S., Cerrano, C., Di Camillo, C. G., and Bavestrello, G. (2008). Hydroidomedusae (Cnidaria: Hydrozoa) symbiotic radiation. Journal of the Marine Biological Association of the United Kingdom 88, 1715-1721. doi:10.1017/S0025315408002233 </jrn>

<jrn>Rees, W. J. (1957). Evolutionary trends in the classification of the capitate hydroids and medusae. Bulletin of the British Museum (Natural History). Zoology Series 4, 455-534.</jrn>

<jrn>Reimer, J. D., Herrera, M., Gatins, R., Roberts, M. B., Parkinson, J. E., and Berumen, M. L. (2017). Latitudinal variation in the symbiotic dinoflagellate Symbiodinium of the common reef zoantharian Palythoa tuberculosa on the Saudi Arabian coast of the Red Sea. Journal of Biogeography 44, 661-673. doi:10.1111/jbi.12795</jrn> 
Publisher: CSIRO; Journal: IS:Invertebrate Systematics

Article Type: research-article; Volume: ; Issue: ; Article ID: IS16091

DOI: 10.1071/IS16091; TOC Head:

<jrn>Ronquist, F., Teslenko, M., van der Mark, P., Ayres, D. L., Darling, A., Hohna, S., Larget, B., Liu, L., Suchard,

M. A., and Huelsenbeck, J. P. (2012). MrBayes 3.2: efficient Bayesian phylogenetic inference and model choice

across a large model space. Systematic Biology 61, 539-542. doi:10.1093/sysbio/sys029</jrn>

$<\mathrm{jrn}>$ Rotch, W. D. (1871). On a new genus and species of hydroid zoophytes (Cladocoryne floccosa). Annals \&

Magazine of Natural History 7, 227-228. doi:10.1080/00222937108696352</jrn>

<edb>Rützler, K. (1978). Sponges in coral reefs. In 'Coral Reefs: Research Methods. Monographs on Oceanographic

Methodology 5'. (Eds D. R. Stodart and R. E. Johanes.) pp. 299-313. (UNESCO: Paris, France.)</edb>

<jrn>Schuchert, P., and Reiswig, H. M. (2006). Brinckmannia hexactinellidophila, n. gen., n. sp.: a hydroid living in tissues of glass sponges of the reefs, fjords, and seamounts of Pacific Canada and Alaska. Canadian Journal of

Zoology 84, $564-572$. doi:10.1139/z06-031</jrn>

<jrn>Schulze, F. E. (1876). Tiarella singularis, ein neuer hydroidpolyp. Zeitschrift fur Wissenschartliche Zoologie 27,

403-416. </jrn>

$<\mathrm{jrn}>$ Schulze, F. E. (1880). On the structure and arrangement of the soft parts in Euplectella aspergillum. Transactions of the Royal Society of Edinburgh 29, 661-673. doi:10.1017/S0080456800026181</jrn>

<jrn>Seveso, D., Montano, S., Reggente, M. A. L., Maggioni, D., Orlandi, I., Galli, P., and Vai, M. (2017). The cellular stress response of the scleractinian coral Goniopora columna during the progression of the black band disease. Cell Stress \& Chaperones 22, 225-236. doi:10.1007/s12192-016-0756-7</jrn>

<ths>Shimabukuro, V. (2007). As associações epizóicas de Hydrozoa (Cnidaria: Leptothecata, Anthoathecata e

Limnomedusae): I) estudo faunístico de hidrozoários epizóicos e seus organismos associados; II) dinâmica de comunidades bentônicas em substratos artificiais em São Sebastião, SP. Master’s thesis, Universidade de São Paulo,

Brazil.</ths $>$

<jrn>Shimabukuro, V., Marques, A. C., and Migotto, A. E. (2006). The anthoathecate hydroid fauna (Hydrozoa,

Anthoathecata) of the coast of Ceará State, Brazil. Biota Neotropica 6, 1-13. doi:10.1590/S1676-

$\underline{06032006000300009}</$ jrn $>$

<jrn>Stechow, E. (1919). Zur Kenntnis der Hydroidenfauna des Mittelmeeres, Amerikas und anderer Gebiete, nebst

Angaben über einige Kirchenpauer'sche Typen von Plumulariden. Zoologische Jahrbucher. Abteilung fur

Systematik, Geographie und Biologie der Tiere 42, 1-172.</jrn>

<jrn>Sukumaran, J., and Holder, M. T. (2010). DendroPy: a Python library for phylogenetic computing. Bioinformatics 26, 1569-1571. doi:10.1093/bioinformatics/btq228/jrn>

<jrn>Talavera, G., and Castresana, J. (2007). Improvement of phylogenies after removing divergent and ambiguously aligned blocks from protein sequence alignments. Systematic Biology 56, 564-577.

doi:10.1080/10635150701472164</jrn>

<jrn>Tamura, K., Stecher, G., Peterson, D., Filipski, A., and Kumar, S. (2013). MEGA6: molecular evolutionary genetics analysis version 6.0. Molecular Biology and Evolution 30, 2725-2729. doi:10.1093/molbev/mst197</jrn>

<jrn>Tyler, J. C., and Böhlke, J. E. (1972). Records of sponge-dwelling fishes, primarily of the Caribbean. Bulletin of Marine Science 22, 601-642.</jrn> 
Publisher: CSIRO; Journal: IS:Invertebrate Systematics

Article Type: research-article; Volume: ; Issue: ; Article ID: IS16091

DOI: 10.1071/IS16091; TOC Head:

<jrn>Uriz, M. J., Rosell, D., and Maldonado, M. (1992). Parasitism, commensalism or mutualism? The case of

Scyphozoa (Coronatae) and horny sponges. Marine Ecology Progress Series 81, 247-255.

doi:10.3354/meps081247</jrn>

$<$ jrn>Verrill, A. E. (1865). Classification of polyps. (Extract condensed from a synopsis of the Polypi of the North

Pacific exploring expedition under Captains Ringgold and Rodgers, U.S.N.) Annals \& Magazine of Natural History

16, 191-197.</jrn>

<jrn>Vervoort, W. (1949). Notes on a small collection of hydroids from Jersey (Channel Islands). Zoölogische

Mededeelingen 30, 133-162.</jrn>

<jrn>Wedler, E., and Larson, R. (1986). Athecate hydroids from Puerto Rico and the Virgin Islands. Studies on

Neotropical Fauna and Environment 21, 69-101. doi:10.1080/01650528609360698</jrn>

<jrn>Wulff, J. L. (2006). Ecological interactions of marine sponges. Canadian Journal of Zoology 84, 146-166. doi:10.1139/z06-019</jrn>

<jrn>Yamada, M., and Konno, K. (1973). Polyp and medusa of the hydroid Sphaerocoryne multitentaculata (Warren) from Japan. Publications of the Seto Marine Biological Laboratory 20, 103-109.</jrn>

<jrn>Zietara, M. S., Arndt, A., Geets, A., Hellemans, B., and Volckaert, F. A. (2000). The nuclear rDNA region of Gyrodactylus arcuatus and G. branchicus (Monogenea: Gyrodactylidae). The Journal of Parasitology 86, 13681373. doi:10.1645/0022-3395(2000)086[1368:TNRROG]2.0.CO;2</jrn>

<eref>Zwickl, D. (2006). 'Garli: genetic algorithm for rapid likelihood inference'. Available at

http://www.bio.utexas.edu/faculty/antisense/garli/Garli.html [xxx].</eref>

Manuscript received 24 December 2016, accepted 10 April 2017

Handling editor: Greg Rouse

Fig. 1. Bayesian inference tree obtained from the concatenated dataset of nuclear $18 S$ and $28 S$ loci and mitochondrial $16 S$ gene under the GTR+G+I model. Black circles on nodes indicate Bayesian posterior probabilities $(\mathrm{BPP})>0.95$ and bootstrap support $(\mathrm{BS})>75$ on combined analysis, whereas grey circles indicate BS $>75$ and white circles indicate BPP $>0.95$. Node values represent BPP on single-gene $16 \mathrm{~S}-18 \mathrm{~S}-28 \mathrm{~S}$ analyses; $\times$ indicates that one of the taxa is not included in the analysis; - indicates that the node does not exist.

Fig. 2. (A-M) Polyp stage of Astrocoryne cabela, gen. et sp. nov. (A) Fertile colony associated with Clathria sp. from the Maldives; $(B)$ polyp growing on Haliclona sp. from the Maldives; $(C)$ specimen associated with a tube sponge from Saudi Arabia; $(D)$ photomicrograph of an anesthetised fertile polyp; $(E)$ extended tentacle showing the two clusters of nematocysts; $(F)$ contracted tentacle; $(G)$ detail of the insertion of the pedicel into the hydrorhiza; $(H)$ cup-shaped perisarc covering the basal part of hydranth; $(I)$ fertile polyp with 11 medusa buds at different stages of maturation; $(J)$ blastostyle bearing two medusa buds; $(K)$ desmonemes; $(L)$ microbasic eurytele; $(M)$ stenoteles of three size classes. Scale bars $=A-C 250 \mu \mathrm{m} ; D, I 100 \mu \mathrm{m} ; E-H, J 40 \mu \mathrm{m} ; K-M 5 \mu \mathrm{m}$. Abbreviations: Hy, hydrorhiza; Pe, pedicel; Sp, sponge; sS, small stenotele; $\mathrm{mS}$, medium-sized stenotele; $1 \mathrm{~S}$, large stenotele. 
Fig. 3. (A-J) Medusa stage of Astrocoryne cabela, gen. et sp. nov. from the Maldives. $(A)$ Medusa, a few minutes after release; $(B)$ two-day-old medusa with comparatively longer manubrium and two opposite tentacles; $(C)$ detail of the manubrium and the protrusions on the apical part of exumbrella; $(D)$ basal view of a medusa; $(E)$ extended tentacle; $(F)$ detail of the nematocyst-rich terminal swelling of a tentacle; $(G)$ microbasic eurytele; $(H)$ microbasic mastigophore; (I) stenotele; $(J)$ desmonemes. Scale bars $=A, B 100 \mu \mathrm{m} ; C-E 50 \mu \mathrm{m} ; F-J 5 \mu \mathrm{m}$.

Fig. 4. (A-I) Astrocoryne cabela, gen. et sp. nov. (A) Fertile polyp from the Maldives; $(B)$ polyp from Saudi Arabia; $(C)$ medusa from the Maldives; $(D)$ large stenotele; $(E)$ medium-sized stenotele; $(F)$ small stenotele; $(G)$ microbasic mastigophore; $(H)$ desmoneme; $(I)$ microbasic eurytele. Scale bar $=A-C 200 \mu \mathrm{m} ; D-I 20 \mu \mathrm{m}$.

Fig. 5. Type and arrangement of tentacles in Sphaerocorynidae: (A) Sphaerocoryne; $(B)$ Heterocoryne; $(C)$ Astrocoryne.

Fig. 6. Different type of tentacles and their possible evolution. (A) Primordial nematocyst button; $(B)$ capitate tentacle; $(C)$ dicapitate tentacle; $(D)$ moniliform tentacle; $(E)$ capitate tentacles in multiple whorls; $(F)$ partially fused capitate tentacles that may have derived from partial duplication (black arrow) or partial fusion (white arrow) events.

Table 1. Specimens included in the analyses and associated GenBank accession numbers

\begin{tabular}{|c|c|c|c|c|c|c|c|}
\hline \multirow[t]{2}{*}{ Family } & \multirow[t]{2}{*}{ Genus } & \multirow[t]{2}{*}{ Species } & \multirow[t]{2}{*}{ Specimen code } & \multirow[t]{2}{*}{ Locality } & \multicolumn{3}{|c|}{ GenBank accession numbers } \\
\hline & & & & & $16 S$ & $18 S$ & $28 S$ \\
\hline Asyncorynidae & Asyncoryne & ryniensis & KUNHM2639 & Japan & $\begin{array}{c}\text { EU8765 } \\
52\end{array}$ & $\begin{array}{c}\text { EU87657 } \\
8\end{array}$ & $\begin{array}{c}\text { GQ42428 } \\
9\end{array}$ \\
\hline Cladocorynidae & Cladocoryne & floccosa & LEM S40/AL1407 & Brazil & $\begin{array}{c}\text { KT2666 } \\
07\end{array}$ & $\begin{array}{c}\text { EU27260 } \\
8\end{array}$ & $\begin{array}{c}\text { KT75717 } \\
3\end{array}$ \\
\hline Cladocorynidae & Cladocoryne & haddoni & MA200 & Maldives & $\begin{array}{l}\text { LT5938 } \\
65\end{array}$ & $\begin{array}{c}\text { LT59387 } \\
5\end{array}$ & $\begin{array}{c}\text { LT59387 } \\
0\end{array}$ \\
\hline Cladocorynidae & Pteroclava & krempfi & MA181 & Maldives & $\begin{array}{l}\mathrm{LT} 1582 \\
09\end{array}$ & $\begin{array}{c}\text { LT59387 } \\
6\end{array}$ & $\begin{array}{c}\text { LT22203 } \\
9\end{array}$ \\
\hline $\begin{array}{l}\text { Hydrocorynida } \\
\mathrm{e}\end{array}$ & Hydrocoryne & miurensis & KUNHM2814 & Japan & $\begin{array}{c}\text { GQ3953 } \\
26\end{array}$ & - & $\begin{array}{c}\text { GQ42431 } \\
3\end{array}$ \\
\hline Milleporidae & Mille & alcicornis & $\begin{array}{l}\text { AGC2001/AMN20 } \\
08\end{array}$ & - & $\begin{array}{c}\text { EU8765 } \\
51\end{array}$ & $\begin{array}{c}\mathrm{AF} 35808 \\
8\end{array}$ & $\begin{array}{c}\text { EU87995 } \\
0\end{array}$ \\
\hline Moerisiidae & Moerisia & $\begin{array}{l}\text { inkermani } \\
\text { ca }\end{array}$ & LEM m3x S41 & Brazil & $\begin{array}{c}\text { KT2666 } \\
26\end{array}$ & $\begin{array}{c}\text { KT72240 } \\
8\end{array}$ & $\begin{array}{c}\text { KT75716 } \\
1\end{array}$ \\
\hline Moerisiidae & Odessia & maeotica & $\begin{array}{l}\text { MHNGINVE5364 } \\
2\end{array}$ & France & $\begin{array}{c}\text { GQ3953 } \\
4\end{array}$ & $\begin{array}{c}\text { GQ42434 } \\
1\end{array}$ & GQ42434 \\
\hline Pennariidae & Pennaria & disticha & MZUSP:1670 & Brazil & $\begin{array}{c}\text { KT2666 } \\
35\end{array}$ & $\begin{array}{c}\text { KT72242 } \\
1\end{array}$ & $\begin{array}{c}\text { KT75712 } \\
9\end{array}$ \\
\hline Porpitidae & Porpita & por & CWD147 & - & $\begin{array}{c}\text { AY } 9353 \\
22\end{array}$ & $\begin{array}{c}\text { GQ42431 } \\
9\end{array}$ & $\begin{array}{c}\text { EU88355 } \\
1\end{array}$ \\
\hline Porpitidae & Velella & velella & $\operatorname{Sch} 71$ & France & $\begin{array}{c}\text { EU3054 } \\
87\end{array}$ & $\begin{array}{c}\text { EU87657 } \\
6\end{array}$ & $\begin{array}{c}\text { EU87994 } \\
9\end{array}$ \\
\hline Solanderiidae & Solanderia & ericopsis & $\begin{array}{l}\text { MHNGINVE2959 } \\
3\end{array}$ & $\begin{array}{l}\text { New } \\
\text { Zealand }\end{array}$ & $\begin{array}{l}\text { AY5125 } \\
30\end{array}$ & $\begin{array}{c}\text { EU27263 } \\
6\end{array}$ & $\begin{array}{c}\text { EU27259 } \\
3\end{array}$ \\
\hline Solande & Solanderia & secunda & KUNHM 2611 & Japan & $\begin{array}{c}\text { EU3054 } \\
84\end{array}$ & $\begin{array}{c}\text { EU30550 } \\
2\end{array}$ & $\begin{array}{c}\text { EU30553 } \\
3\end{array}$ \\
\hline $\begin{array}{l}\text { Sphaerocorynid } \\
\text { ae }\end{array}$ & Astro & cabela & KA175 & $\begin{array}{l}\text { Saudi } \\
\text { Arabia }\end{array}$ & $\begin{array}{l}\text { LT7141 } \\
73\end{array}$ & $\begin{array}{c}\text { LT71417 } \\
4\end{array}$ & $\begin{array}{c}\text { LT71417 } \\
5\end{array}$ \\
\hline $\begin{array}{l}\text { Sphaerocorynid } \\
\text { ae }\end{array}$ & Astrocoryne & cabela & MA217 & Maldives & $\begin{array}{l}\text { LT7141 } \\
76\end{array}$ & $\begin{array}{c}\text { LT71417 } \\
7\end{array}$ & $\begin{array}{c}\text { LT71417 } \\
8\end{array}$ \\
\hline $\begin{array}{l}\text { Sphaerocorynid } \\
\text { ae }\end{array}$ & Astrocoryne & cabela & MA218 & Maldives & $\begin{array}{l}\text { LT7141 } \\
79\end{array}$ & $\begin{array}{c}\mathrm{LT} 71418 \\
0\end{array}$ & $\begin{array}{c}\text { LT71418 } \\
1\end{array}$ \\
\hline $\begin{array}{l}\text { Sphaerocorynid } \\
\text { ae }\end{array}$ & $\begin{array}{l}\text { Heterocoryn } \\
e\end{array}$ & $\begin{array}{l}\text { caribbensi } \\
s\end{array}$ & SE005 & $\begin{array}{l}\text { St } \\
\text { Eustatius }\end{array}$ & $\begin{array}{l}\text { LT7141 } \\
85\end{array}$ & $\begin{array}{c}\text { LT71418 } \\
6\end{array}$ & $\begin{array}{c}\text { LT71418 } \\
7\end{array}$ \\
\hline $\begin{array}{l}\text { Sphaerocorynid } \\
\text { ae }\end{array}$ & $\begin{array}{l}\text { Sphaerocory } \\
\text { ne }\end{array}$ & sp. & MA205 & Maldives & $\begin{array}{l}\text { LT7141 } \\
\quad 82\end{array}$ & $\begin{array}{c}\text { LT71418 } \\
3\end{array}$ & $\begin{array}{c}\text { LT71418 } \\
4\end{array}$ \\
\hline
\end{tabular}


Publisher: CSIRO; Journal: IS:Invertebrate Systematics

Article Type: research-article; Volume: ; Issue: ; Article ID: IS16091

DOI: 10.1071/IS16091; TOC Head:

\begin{tabular}{|c|c|c|c|c|c|c|c|}
\hline $\begin{array}{l}\text { Sphaerocorynid } \\
\text { ae }\end{array}$ & $\begin{array}{l}\text { Sphaerocory } \\
\text { ne }\end{array}$ & agassizii & PCSphAg/PC005 & Florida & $\begin{array}{c}\text { GQ3953 } \\
23\end{array}$ & - & $\begin{array}{c}\text { GQ42431 } \\
8\end{array}$ \\
\hline Zancleidae & Zanclea & costata & $\begin{array}{l}\text { MHNGINVE2650 } \\
7\end{array}$ & France & $\begin{array}{c}\text { AY5125 } \\
31\end{array}$ & $\begin{array}{c}\text { EU87657 } \\
9\end{array}$ & $\begin{array}{c}\text { EU87995 } \\
1\end{array}$ \\
\hline Zancleidae & Zanclea & gallii & MA058 & Maldives & $\begin{array}{c}\text { LN7141 } \\
07\end{array}$ & $\begin{array}{c}\text { LT59387 } \\
4\end{array}$ & $\begin{array}{c}\text { LT59386 } \\
9\end{array}$ \\
\hline Zancleidae? & Zanclea & prolifera & KUNHM2793 & Japan & $\begin{array}{c}\text { EU3054 } \\
88\end{array}$ & $\begin{array}{c}\text { EU27263 } \\
9\end{array}$ & $\begin{array}{c}\text { EU27259 } \\
8\end{array}$ \\
\hline \multicolumn{8}{|l|}{ Outgroups } \\
\hline Corynidae & $\begin{array}{l}\text { Stauridiosars } \\
\text { ia }\end{array}$ & $\begin{array}{l}\text { ophiogaste } \\
r\end{array}$ & KUNHM 2803 & Japan & $\begin{array}{c}\text { EU3054 } \\
73\end{array}$ & $\begin{array}{c}\text { EU27261 } \\
5\end{array}$ & $\begin{array}{c}\text { EU27256 } \\
0\end{array}$ \\
\hline Corynidae & Sarsia & striata & $\begin{array}{l}\text { MHNGINVE3576 } \\
5\end{array}$ & Scotland & $\begin{array}{c}\text { GQ3953 } \\
28\end{array}$ & $\begin{array}{c}\text { GQ42433 } \\
8\end{array}$ & $\begin{array}{c}\text { GQ42431 } \\
1\end{array}$ \\
\hline Corynidae & Coryne & uchidai & $\begin{array}{l}\text { MHNGINVE4910 } \\
2\end{array}$ & Japan & $\begin{array}{c}\text { GQ3953 } \\
20\end{array}$ & $\begin{array}{c}\text { GQ42433 } \\
2\end{array}$ & $\begin{array}{c}\text { GQ42430 } \\
6\end{array}$ \\
\hline Corynidae & Scrippsia & pacifica & - & $\begin{array}{l}\text { Californi } \\
\text { a }\end{array}$ & $\begin{array}{c}\text { AY5125 } \\
51\end{array}$ & $\begin{array}{c}\text { AF35809 } \\
1\end{array}$ & $\begin{array}{c}\text { AY92080 } \\
4\end{array}$ \\
\hline $\begin{array}{l}\text { Cladonematida } \\
\mathrm{e}\end{array}$ & Staurocladia & $\begin{array}{l}\text { wellington } \\
i\end{array}$ & $\begin{array}{l}\text { MHNGINVE2537 } \\
9\end{array}$ & $\begin{array}{l}\text { New } \\
\text { Zealand }\end{array}$ & $\begin{array}{c}\text { AY7878 } \\
82\end{array}$ & $\begin{array}{c}\text { GQ42432 } \\
3\end{array}$ & $\begin{array}{c}\text { EU87994 } \\
8\end{array}$ \\
\hline Pticlocodiidae & $\begin{array}{l}\text { Hydrichthell } \\
a\end{array}$ & epigorgia & KUNHM 2665 & Japan & $\begin{array}{c}\text { EU3054 } \\
78\end{array}$ & $\begin{array}{c}\text { EU27262 } \\
2\end{array}$ & $\begin{array}{c}\text { EU27256 } \\
9\end{array}$ \\
\hline Candelabridae & $\begin{array}{l}\text { Candelabru } \\
m\end{array}$ & cocksi & $\begin{array}{l}\text { MHNGINVE2959 } \\
1\end{array}$ & France & $\begin{array}{c}\text { AY5125 } \\
20\end{array}$ & $\begin{array}{c}\text { EU87655 } \\
6\end{array}$ & $\begin{array}{c}\text { EU87992 } \\
8\end{array}$ \\
\hline Olindiidae & Olindias & $\begin{array}{l}\text { phosphori } \\
\text { ca }\end{array}$ & $\begin{array}{l}\text { MHNGINVE2981 } \\
1\end{array}$ & Spain & $\begin{array}{c}\text { AY5125 } \\
09 \\
\end{array}$ & $\begin{array}{c}\text { AY92075 } \\
3 \\
\end{array}$ & $\begin{array}{c}\text { EU24780 } \\
8 \\
\end{array}$ \\
\hline
\end{tabular}

Table 2. Comparative measurements of Astrocoryne cabela (in micrometre) based on specimens from the Maldives and Saudi Arabia

\begin{tabular}{lcc}
\hline & Maldives & Locality \\
& & Red Sea \\
\hline Hydranth & $600-800$ & $400-600$ \\
Length & $90-100$ & $65-75$ \\
Diameter at base & $200-240$ & $200-250$ \\
Diameter at tentacle portion & $65-70$ & $40-50$ \\
Diameter at the base of hypostome & $200-250$ & $100-120$ \\
Length of hypostome & & \\
Pedicel & Cup-shaped & Tubular \\
Shape & $90-190$ & $450-480$ \\
Length & $80-100$ & $50-65$ \\
Diameter & & \\
Tentacles & $8-10$ & $8-9$ \\
Number & $350-500$ & $200-500$ \\
Length & 1 & 2 \\
Whorls & $50-85$ & $55-60$ \\
Diameter of terminal capitula & $80-110$ & $65-70$ \\
Diameter of proximal 'capitula' & & \\
Cnidome & $5-6 \times 4-5$ & $6 \times 4-5$ \\
Small stenoteles & $9-10 \times 5-6$ & $8-9 \times 5-7$ \\
Medium-sized stenoteles & $18-21 \times 13-16$ & $19-20 \times 14-17$ \\
Large stenoteles & $7-8 \times 4$ & $7-9 \times 4-5$ \\
Desmonemes & $13-15 \times 5-6$ & $14-15 \times 5-6$ \\
Microbasic euryteles & & \\
\hline
\end{tabular}


$\mathrm{BS}>75, \mathrm{BPP}>0.95$

O $B S>75$
O $\mathrm{BPP}>0.95$

Asyncoryne ryniensis

Zanclea prolifera

Millepora alcicornis

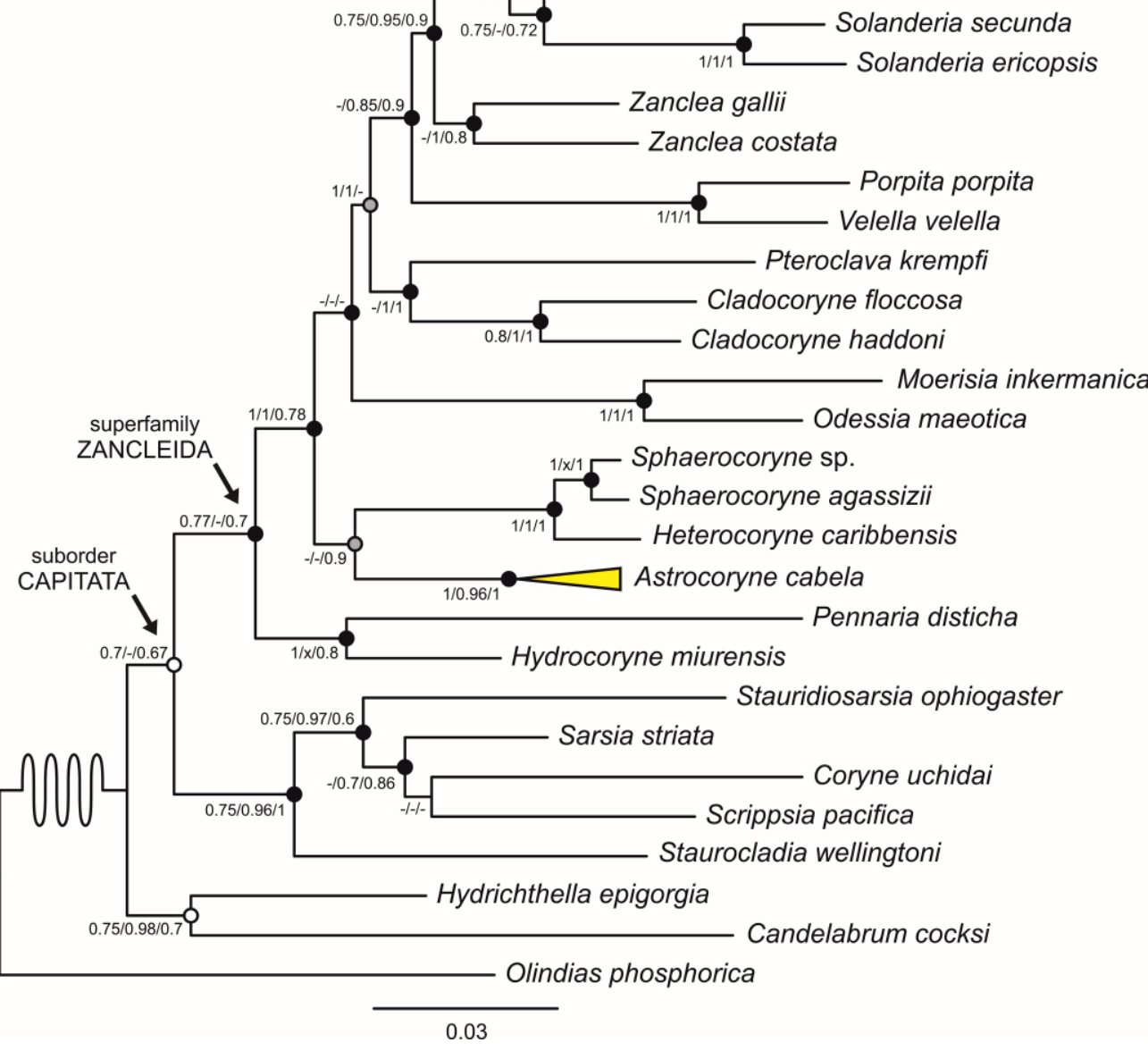

I ASYNCORYNIDAE

I MILLEPORIDAE

SOLANDERIIDAE

ZANCLEIDAE

PORPITIDAE

CLADOCORYNIDAE

MOERISIIDAE

SPHAEROCORYNIDAE

I PENNARIIDAE

I HYDROCORYNIDAE

Outgroups

Fig. 1 


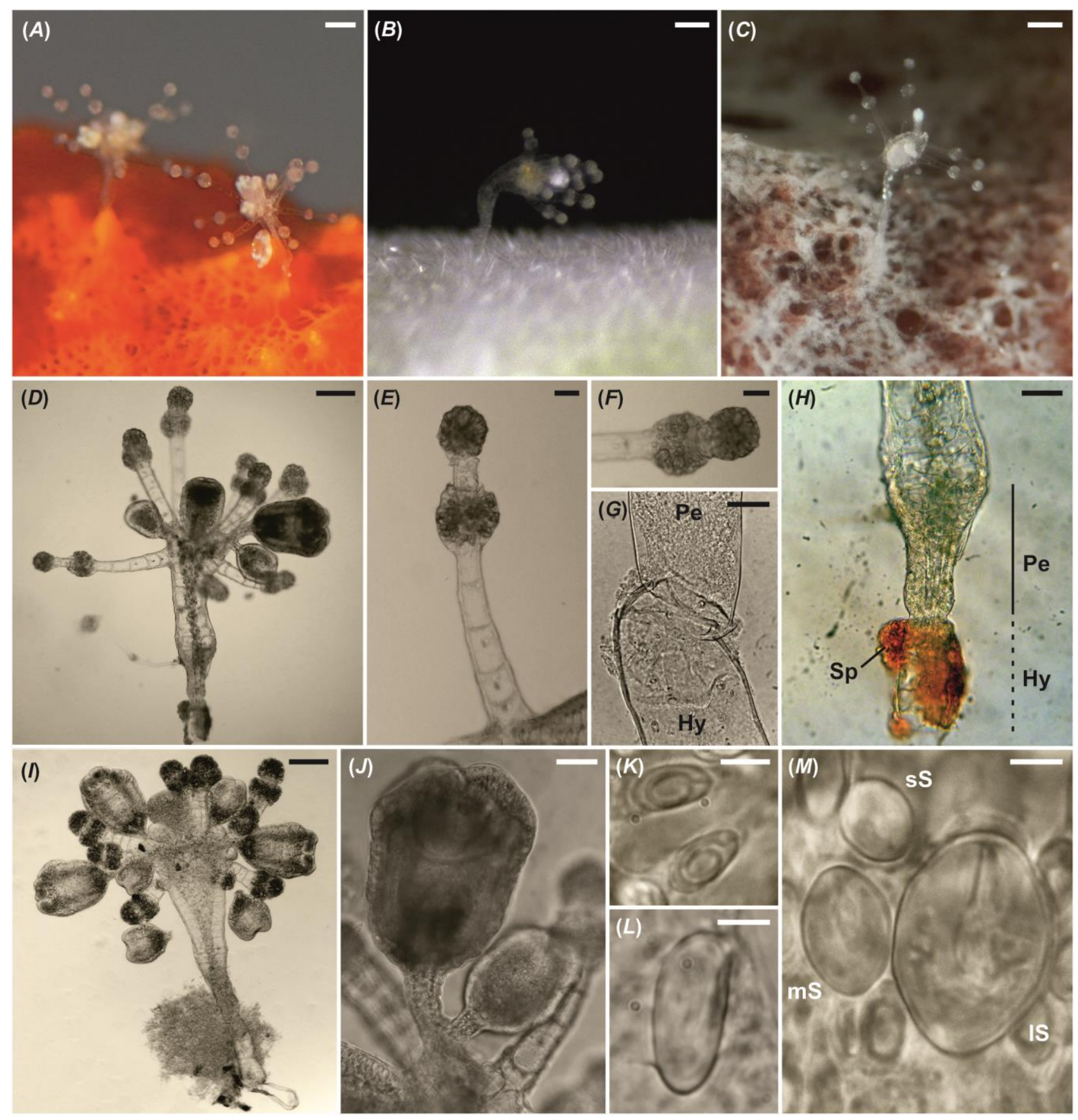

Fig. 2 

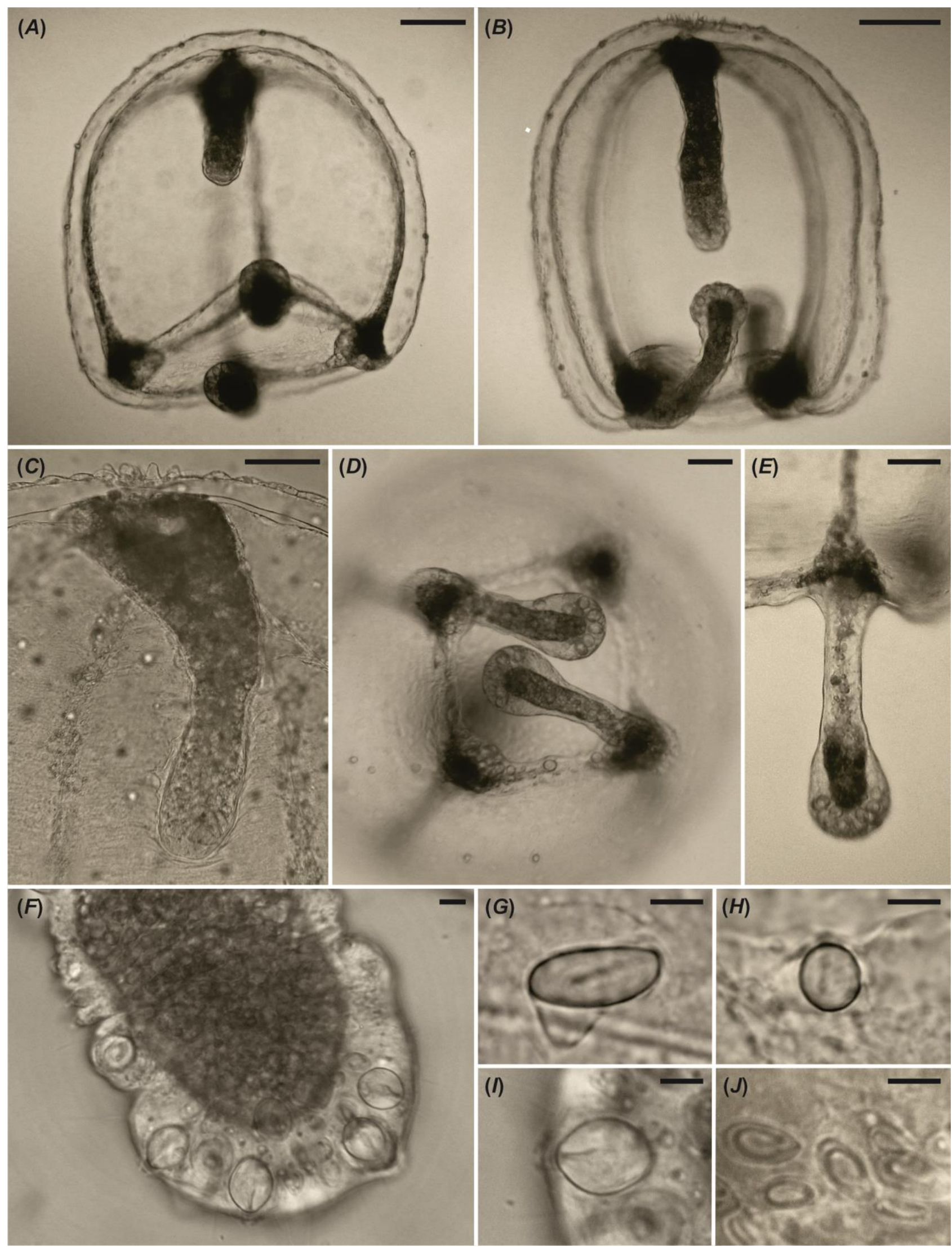

Fig. 3 


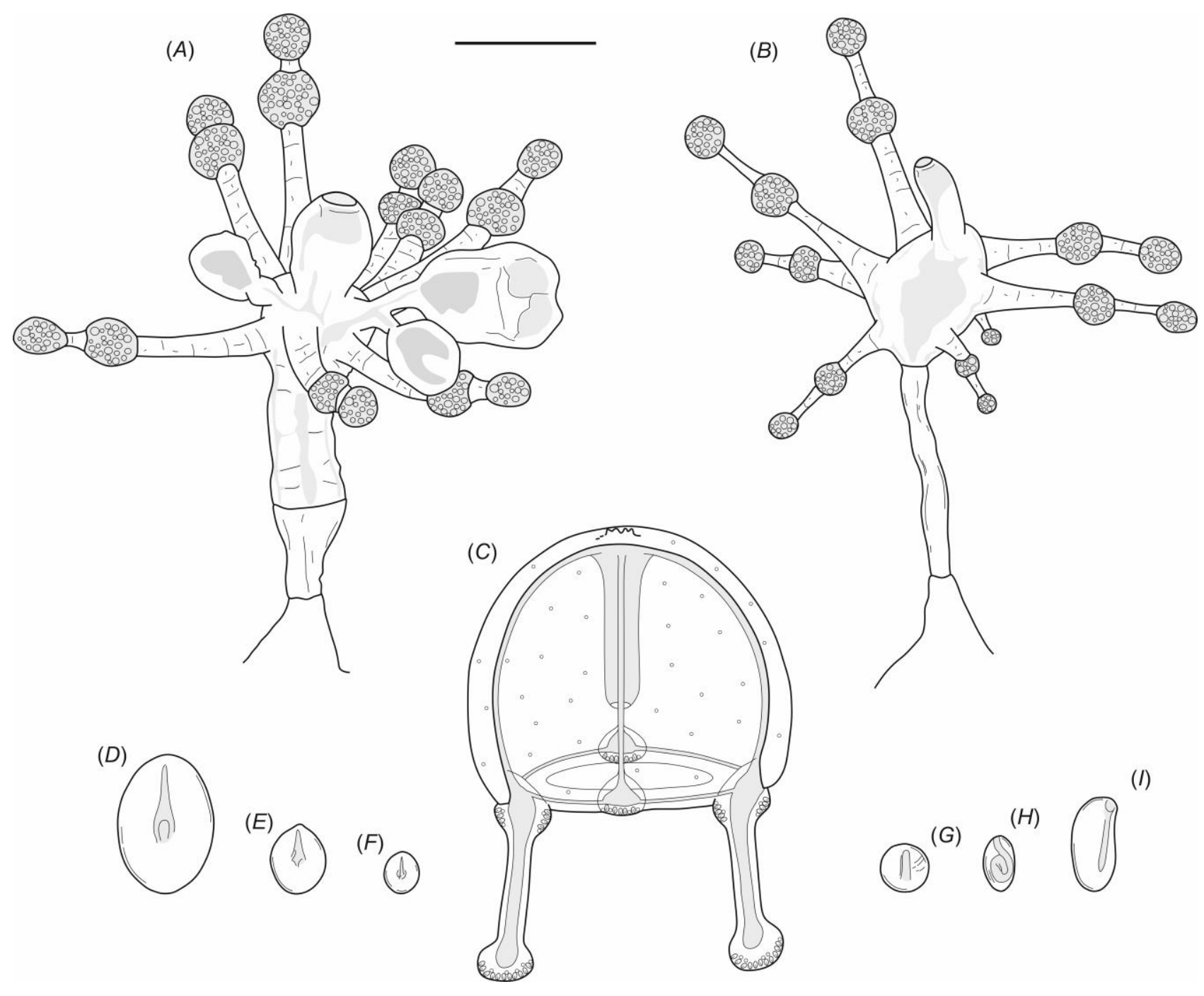

Fig. 4 

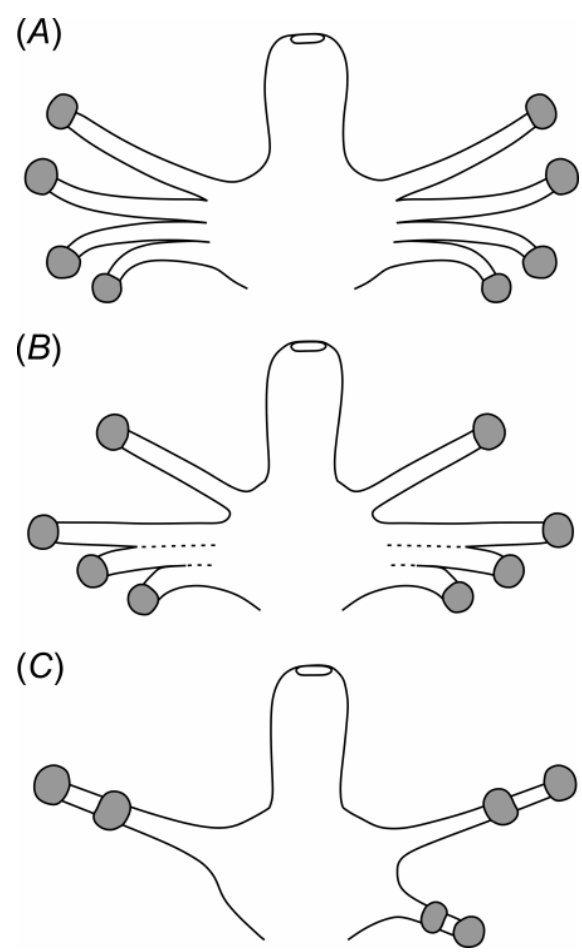

Fig. 5 
meristic changes along

the proximal-distal axis

(B)

(C) $\quad(D)$

(A)

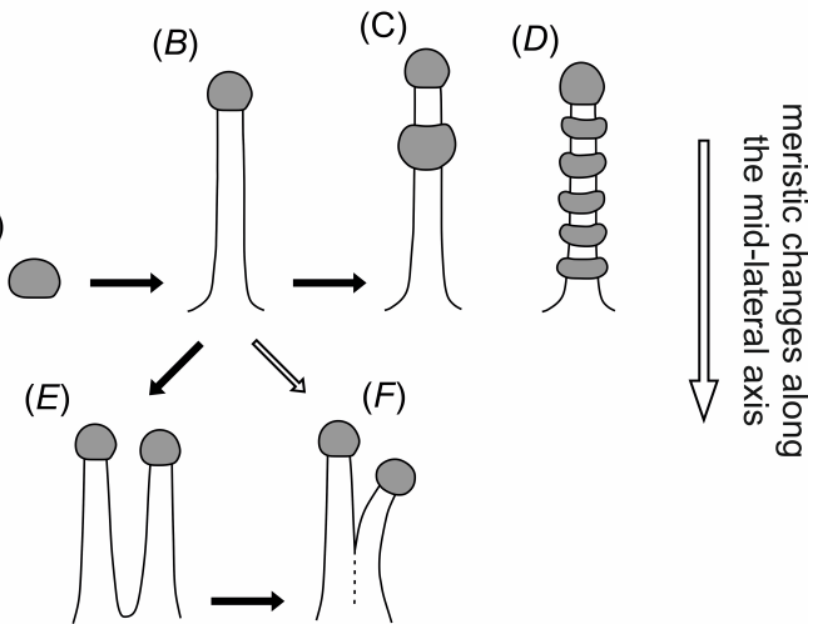

Fig. 6 